\title{
Pengaruh Penerapan Good Corporate Governance dan Solvabilitas Terhadap Peringkat Obligasi Pada Industri Perbankan
}

\author{
Tati Saromah ${ }^{1}$, Choiroel Woestho ${ }^{1, *}$ \\ ${ }^{1}$ Fakultas Ekonomi dan Bisnis; Universitas Bhayangkara Jakarta Raya; Jl. Perjuangan No 81, \\ Bekasi; Telp. (021) 7231948; e-mail: tatisaromah5@gmail.com, choiroel@dsn.ubharajaya.ac.id \\ * Korespondensi: e-mail: choiroel@dsn.ubharajaya.ac.id
}

Submitted: 14/08/2021; Revised: 18/11/2021; Accepted: 27/11/2021; Published: $31 / 12 / 2021$

\begin{abstract}
This research was conducted to determine how the effect of the implementation of good corporate governance and solvency on bond ratings. This research is conducted because there is still little research on the prediction of bond ratings in Indonesia. This is due to the limited data on bonds and investors' understanding of bonds. The purpose of this study are to determine the partial and simultaneous effect of good corporate governance and solvency on bond ratings in the banking industry in 2007-2015. The research analysis method used in this research is Multiple Discriminant Analysis (MDA) which consists of classical assumption tests, multiple linear regression tests, and hypothesis testing. This type of research is quantitative using secondary data and the sampling technique used is purposive sampling. The results in this study are partially Good Corporate Governance (X1) has a significant positive effect on bond ratings $(Y)$, and Solvency $(X 2)$ has no effect on bond ratings $(Y)$, as well as simultaneously Good Corporate Governance (X1) and Solvency (X2). ) has a significant effect on bond ratings $(Y)$.
\end{abstract}

Keywords: Bond Ratings, Good Corporate Governance, Solvency Ratio

\begin{abstract}
Abstrak
Penelitian ini dilakukan untuk mengetahui bagaimana pengaruh penerapan good corporate governance dan solvabilitas terhadap peringkat obligasi. Penelitian ini dilakukan karena masih sedikit penelitian tentang prediksi peringkat obligasi di Indonesia. Hal ini disebabkan terbatasnya data obligasi dan pemahaman investor terhadap obligasi Tujuan dalam penelitian ini adalah untuk mengetahui pengaruh secara parsial dan simultan antara good corporate governance dan solvabilitas terhadap peringkat obligasi pada industri perbankan tahun 20072015. Metode analisis penelitian yang digunakan dalam penelitian ini adalah Multiple Discriminant Analysis (MDA) yang terdiri dari uji asumsi klasik, uji regresi linier berganda, dan uji hipotesis. Jenis penelitian ini adalah kuantitatif dengan menggunakan data sekunder dan teknik pengambilan sampel yang digunakan adalah purposive sampling. Hasil dalam penelitian ini adalah secara parsial Good Corporate Governance (X1) berpengaruh positif signifikan terhadap peringkat obligasi $(\mathrm{Y})$, dan Solvabilitas $(\mathrm{X} 2)$ tidak berpengaruh terhadap peringkat obligasi(Y), serta secara simultan Good Corporate Governance (X1) dan Solvabilitas (X2) berpengaruh signifikan terhadap peringkat obligasi $(\mathrm{Y})$.
\end{abstract}

Kata kunci: Peringkat Obligasi, Prinsip Tata Kelola Perusahaan, Rasio Solvabilitas 


\section{Pendahuluan}

Di pasar modal, ada berbagai macam instrumen sekuritas. Dua jenis investasi yang paling umum digunakan yaitu investasi saham dan investasi obligasi. Di Indonesia, pemahaman tentang obligasi masih relatif rendah, dikarenakan informasi obligasi yang tersedia untuk publik tidak sebanyak informasi saham. Padahal investor yang investasi pada instrumen obligasi akan menerima keuntungan secara periodik.

Bagi perusahaan atau pemerintah, obligasi merupakan alternatif yang menarik untuk pembiayaan hutang, karena obligasi biasanya memiliki jangka waktu yang lebih lama dan relatif.murah, karena obligasi merupakan proses hutang langsung kepada masyarakat (penyedia modal). Sebelum menawarkan obligasi kepada investor, obligasi akan di rating oleh lembaga pemeringkat terlebih dahulu. Proses pemeringkatan ini bertujuan guna mengevaluasi prestasi suatu perusahaan berdasarkan berbagai aspek yang secara langsung ataupun tidak berkaitan dengan finansial perusahaan. Karena obligasi adalah sekuritas hutang, maka memerlukan pemeringkatan untuk memperkirakan apakah semua utangnya dapat dibayar kembali atau tidak oleh penerbit.

Saat ini terdapat sekitar 100 lembaga pemeringkat kredit di dunia, tiga di antaranya disebut sebagai lembaga berskala global "Big Three", yaitu Fitch Ratings, Standard \& Poor's dan Moody's. Di Indonesia sendiri terdapat lembaga pemeringkat swasta nasional, PT Pefindo yang beroperasi sejak tahun 1994. Selain itu ada dua lembaga pemeringkat asing, yaitu PT Fitch Ratings, Ltd yang bermarkas di New York dan London, dan PT ICRA Indonesia yang merupakan subsidiary dari lembaga pemeringkat international Moody's Investors Service. Menurut prinsip internasional, kehadiran perusahaan pemeringkat asing di Indonesia telah mendorong pemeringkatan surat utang di pasar modal Indonesia.

PT Pefindo menjadi jasa pemeringkatan obligasi yang banyak digunakan oleh industri yang terdaftar di Bursa Efek Indonesia, hal ini berarti perusahaan. memiliki kepercayaan penuh terhadap evaluasi perusahaan pemeringkat. Oleh karena itu, penelitian ini didasarkan pada hasil pemeringkatan yang.diberikan.oleh.PT.Pefindo dan diharapkan hasil Pefindo dapat memberikan informasi yang relevan. PT Pefindo membedakan jenis investment grade (AAABBB) dan non-investment grade (BB-D) dengan menambahkan ID diawal (singkatan Indonesia).

Di Indonesia, pemahaman tentang obligasi relatif rendah, dikarenakan informasi obligasi yang tersedia untuk publik tidak sebanyak informasi saham. Padahal investor yang investasi pada instrumen obligasi akan menerima keuntungan secara periodik (Amalia, 2013).

Bagi perusahaan atau pemerintah, obligasi merupakan alternatif yang menarik untuk pembiayaan hutang, karena obligasi biasanya memiliki jangka waktu yang lebih lama dan lebih murah, karena obligasi merupakan proses hutang langsung kepada masyarakat (penyedia modal). Sebelum menawarkan obligasi kepada investor, obligasi akan di rating oleh lembaga pemeringkat (Pramono \& Irawan, 2017). 


\section{Pengaruh Penerapan Good Corporate Governance dan Solvabilitas Terhadap Peringkat Obligasi Pada Industri Perbankan}

Sejumlah penelitian menyimpulkan bahwa peringkat obligasi dipengaruhi oleh mekanisme dan implementasi tata kelola perusahaan. Menurut (Janiman et al., 2017) Skor CGPI yang didapat melalui IICG (The Indonesian Institute for Corporate Governance) dapat mempengaruhi peringkat obligasi. Perusahaan dengan tata kelola yang baik, mendapatkan peringkat obligasi yang terpercaya, sehingga stakeholder akan memiliki persepsi yang baik terhadap perusahaan tersebut.

Corporate governance adalah sistem yang digunakan untuk memimpin dan mengontrol perusahaan (Sunarjanto \& Tulasi, 2013). Sementara itu, (Sari \& Yasa, 2016) Good Corporate Governance berpengaruh positif dan signifikan terhadap peringkat obligasi. Korelasi positif antara peringkat obligasi dengan penerapan tata kelola perusahaan yang baik, merupakan salah satu informasi yang dapat digunakan investor untuk menentukan apakah suatu obligasi merupakan investasi yang baik.

Ada faktor - faktor yang dapat dipertimbangkan ketika menentukan peringkat obligasi, antara lain berbagai rasio keuangan, persyaratan kontrak, perlindungan dan kualitas manajemen aset yang ada oleh Lembaga pemeringkat (Sunarjanto \& Tulasi, 2013).

Salah satu adalah rasio solvabilitas, rasio solvabilitas dipilih karena 'dapat membuktikan kesanggupannya untuk membayar semua hutang jangka panjang dan jangka pendek. Jika solvabilitas perusahaan tinggi, maka semakin baik elastisitas keuangan perusahaan dan peringkat obligasi, dan semakin kecil kemungkinan perusahaan menghadapi masalah keuangan di masa depan (Titisari et al., 2017)

Berdasarkan penjelasan diatas, peneliti ingin membuktikan apakah benar bahwa Good Corporate Governance dan solvabilitas memiliki pengaruh terhadap peringkat obligasi dan bagaimana Good Corporate Governance dan solvabilitas mempengaruhi peringkat obligasi. Namun dikarenakan terbatasnya waktu penelitian sehingga peneliti hanya mengelola data yang sudah tersedia, yakni pada periode tahun 2007- 2015. Dari penjelasan diatas maka peneliti ingin menyusun penelitian dengan judul "Pengaruh Penerapan Good Corporate Governance dan Solvabilitas Terhadap Peringkat Obligasi pada Industri Perbankan"

Penelitian ini dilakukan untuk menguji pengaruh positif penerapan GCG, dan solvabilitas terhadap peringkat obligasi. Sedangkan manfaatnya baik secara teoritis maupun praktis adalah sebagai wacana untuk menambah informasi, referensi dan wawasan serta memberikan pemahaman yang lebih luas berkaitan dengan penerapan GCG, solvabilitas dan peringkat obligasi dalam melakukan investasi di pasar modal.

\section{Metode Penelitian}

Variabel independen pada penelitian ini adalah Good Corporate Governance diproksikan dengan Corporate Governance Perception Index (CGPI) yang dilakukan oleh Indonesian Institute of Corporate Governance (IICG).

Good Corporate Governance adalah seperangkat peraturan yang mengatur tentang hak dan kewajiban pemangku kepentingan manajemen, kreditur, pemerintah, pegawai, dan 
pemangku kepentingan internal dan eksternal lainnya, dengan kata lain merupakan sistem pembinaan dan pengendalian perusahaan (Sunarjanto \& Tulasi, 2013).

Alasan munculnya corporate governance adalah untuk memastikan bahwa investor (principal / investor) menggunakan dana yang diinvestasikan dengan benar dan efektif. Selain corporate governance juga memastikan bahwa manajemen bertindak untuk kepentingan terbaik perusahaan (Bhagat \& Bolton, 2019). Berikut adalah kriteria yang menjadi penilaian Good Corporate Governance (GCG)

Tabel 1. Kriteria Penilaian Good Corporate Governance

\begin{tabular}{clc}
\hline No. & \multicolumn{1}{c}{ Kriteria Penilaian } & Bobot (\%) \\
\hline 1. & Komitmen terhadap tata kelola perusahaan & 15 \\
\hline 2. & Hak pemegang saham dan fungsi kepemilikan manajerial & 20 \\
\hline 3. & Perlakuan yangs etara terhadap seluruh pemegang saham & 15 \\
\hline 4. & Peran stakeholder dalam tata kelola perusahaan & 15 \\
\hline 5. & Pengungkapan dan transparansi & 15 \\
\hline 6. & Tanggungjawab dewan komisaris dan dewan direksi & 20 \\
\hline
\end{tabular}

Sumber: Corporate Governance Perception Index (CGPI) (2021)

Variabel berikut yang digunakan dalam penelitian ini adalah rasio solvabilitas. Rasio solvabilitas merupakan salah satu dari rasio keuangan sehingga dapat diperoleh gambaran tentang kondisi keuangan perusahaan (Damayanti \& Fitriyah, 2013).

Solvabilitas perusahaan menunjukkan kemampuan perusahaan dalam memenuhi kewajibannya ketika perusahaan tersebut dilikuidasi. Dengan demikian, solvabilitas adalah kemampuan perusahaan untuk melunasi semua hutang-hutangnya, baik jangka pendek ataupun jangka panjang. Semakin kecil rasio solvabilitas maka semakin kecil angka fleksibilitas keuangan perusahaan, dan semakin besar kemungkinan perusahaan akan menghadapi masalah keuangan di masa yang akan datang. Semakin tinggi tingkat solvabilitas perusahaan maka semakin tinggi pula peringkat perusahaan tersebut. Semakin tinggi solvabilitas perusahaan maka semakin mudah kreditor memberikan kredit karena perusahaan dapat mengurangi risiko yang akan timbul (Ningsih \& Sari, 2019).

Rasio solvabilitas yang digunakan dalam penelitian ini, diproksikan dengan cash flow dari operasi / total kewajiban (CFOTL).

$$
\text { Solvabilitas }=\frac{\text { Cash Flow from Operating }}{\text { Total Liabilities. }}
$$

Variabel terikat yang digunakan dalam penelitian ini adalah peringkat obligasi. Menurut Keputusan Presiden RI No. 775/KMK/001/1982, yang dimaksud dengan obligasi adalah jenis surat berharga yang diperoleh dalam bentuk tertentu, dengan jangka waktu minimal tiga tahun dan menjanjikan pengembalian bunga beserta jumlah pembayaran kembali sesuai dengan ketetapan sebelumnya.

Obligasi merupakan surat berharga yang berisi pengakuan utang yang diterbitkan oleh perusahaan untuk diperjual belikan dengan jangka waktu menengah dan panjang (Sitorus, 2015). Pemegang obligasi akan menerima kupon (interest rate) secara berkala, biasanya setiap 3 atau 6 bulan. 


\section{Pengaruh Penerapan Good Corporate Governance dan Solvabilitas Terhadap Peringkat Obligasi Pada Industri Perbankan}

Dengan demikian, obligasi adalah sekuritas hutang jangka menengah dan panjang yang dapat dialihkan, termasuk komitmen penerbit untuk membayar bunga dalam jangka waktu tertentu dan membayar kembali pokok pinjaman kepada pembeli obligasi pada waktu yang telah ditentukan (Hidayat, 2018).

Peringkat obligasi yang digunakan adalah yang diterbitkan oleh PT. Pefindo dapat diakses dari situs resmi lembaga pemeringkat PT. Pefindo yaitu www.pefindo.com (Bornok Situmorang, 2017). Penelitian ini didasarkan pada klasifikasi kategori pemeringkatan obligasi PT. Pefindo melalui penilaian dan pengawasan hasil kepatuhan dan diakui oleh Bank Indonesia. Pada tabel 1 terdapat klasifikasi peringkat obligasi yaitu sebagai berikut :

Tabel 2. Klasifikasi Peringkat Obligasi

\begin{tabular}{cc}
\hline Kategori Peringkat Obligasi & Nilai Peringkat \\
\hline AAA & 7 \\
\hline AA & 6 \\
\hline A & 5 \\
\hline BBB & 4 \\
\hline BB & 3 \\
\hline B & 2 \\
\hline CCC & 1 \\
\hline D & 0
\end{tabular}

Sumber: PT. Pefindo (2021)

Populasi dalam penelitian ini adalah seluruh perusahaan yang terdaftar dalam pemeringkatan Corporate Governance Perception Index dan terdaftar di Bursa Efek Indonesia tahun 2007-2015. Pemilihan sampel dilakukan menggunakan purposive sampling, yang dipilih sesuai dengan kriteria tertentu. Sampel yang digunakan dalam penelitian ini dipilih berdasarkan kriteria sebagai berikut a) Perusahaan perbankan yang masih aktif pada tahun 2007-2015; b) Terdaftar dalam peringkat obligasi yang dikeluarkan oleh PT. Pefindo; c) Dengan kriteria perusahaan memiliki obligasi denominasi rupiah; d) Perusahaan memiliki skor CGPI yang dikeluarkan oleh IICG.

Jenis data yang digunakan dalam penelitian ini adalah data sekunder. Diperoleh dari BEI, IICG, dan website PT. Pefindo. Sementara Metode analisis menggunakan Multiple Discriminant Analysis (MDA), analisis ini digunakan karena variabel dependen penelitian berbentuk kategorik yaitu peringkat obligasi.

\section{Hasil dan Pembahasan}

\subsection{Uji Asumsi Klasik}

Uji asumsi klasik merupakan syarat yang harus dipenuhi ketika melakukan penelitian dengan menggunakan metode regresi linear ordinary least square (OLS). Dalam analisis regresi menggunakan eviews, ada beberapa uji asumsi klasik yang harus dipenuhi, diantaranya Uji Multikolinearitas, Uji Autokorelasi, Uji Heterokedastisitas, dan Uji Normalitas.

Uji Multikolinearitas ini digunakan untuk menilai apakah model regresi terbentuk karena adanya hubungan atau korelasi antar variabel independent. Uji multikolinieritas merupakan suatu kondisi yang menyatakan hubungan linier antarvariabel independent. Data dikatakan 
tidak terdapat multikolinieritas apabila nilai centered VIF dari variable independent kurang dari 10.

Tabel 3. Uji Multikoliniearitas

\begin{tabular}{ccc}
\hline Variabel & Centered VIF \\
\cline { 2 - 3 } D2 & 1.18045 \\
\hline D3 & 1.096778 \\
\hline C & NA \\
\hline GCG & 1.174257 \\
\hline
\end{tabular}

Sumber: Hasil Penelitian (2021)

Dari hasil pengujian, diperoleh nilai centered VIF pada variable independent yaitu Good Corporate Governance dan Rasio Solvabilitas kurang dari 10. Sehingga dapat disimpulkan tidak terdapat gejala multikolinieritas pada variable independent.

Terakhir, adalah Uji autokorelasi. Uji autokorelasi melihat hubungan antara residual satu observasi dengan residual observasi lainnya. Autokorelasi mudah timbul pada data yang bersifat time-series, karena berdasarkan sifatnya, data saat ini dapat dipengaruhi oleh data pada lampau.

Ada atau tidaknya autokorelasi dapat menggunakan uji Breusch-Godfrey dengan melihat nilai probability terhadap tingkat signifikansinya. Bila nilai probability $>\alpha=5 \%$, berarti tidak ada autokorelasi. Bila nilai probability $\leq \alpha=5 \%$, berarti ada autokorelasi.

Hasil yang diperoleh menunjukkan nilai Prob. Chi Square sebesar 0,9996. Berdasarkan

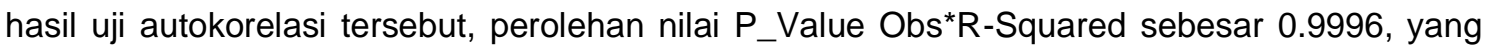
artinya tidak terdapat masalah pada Uji Autokorelasi. Hal ini dikarenakan $0.9996>0.01$ yang membuktikan bahwa tidak adanya masalah Autokorelasi.

Uji heterokedastisitas menunjukkan ketidaksamaan varian dari residual untuk semua pengamatan pada model regresi. Uji Heterokedastisitas bertujuan untuk melihat ada atau tidaknya penyimpangan asumsi klasik. Hasil yang diperoleh Prob. Chi Square sebesar 0,4451. Berdasarkan hasil uji heterokedastisitas tersebut, perolehan nilai $P_{-}$Value Obs* $R$-Squared sebesar 0.4451 maka tidak ditemukan masalah pada Heterokedastisitas. Hal ini dikarenakan $0.4451>0.01$ yang berarti tidak terdapat masalah pada Heterokedastisitas.

Salah satu asumsi dalam analisis statistika yaitu data yang berdistribusi normal. Uji yang digunakan adalah Uji Jargue-Bera dimana uji ini mengukur perbedaan skewness dan kurtosis data dan dibandingkan dengan apabila datanya bersifat normal. Uji Normalitas bertujuan guna mengevaluasi nilai residual yang telah distandarisasi berdistribusi normal atau tidak. Apabila nilai probabilitas Jarque- Bera $>0.05$ maka data berdistribusi normal. 


\section{Pengaruh Penerapan Good Corporate Governance dan Solvabilitas Terhadap Peringkat Obligasi Pada Industri Perbankan}

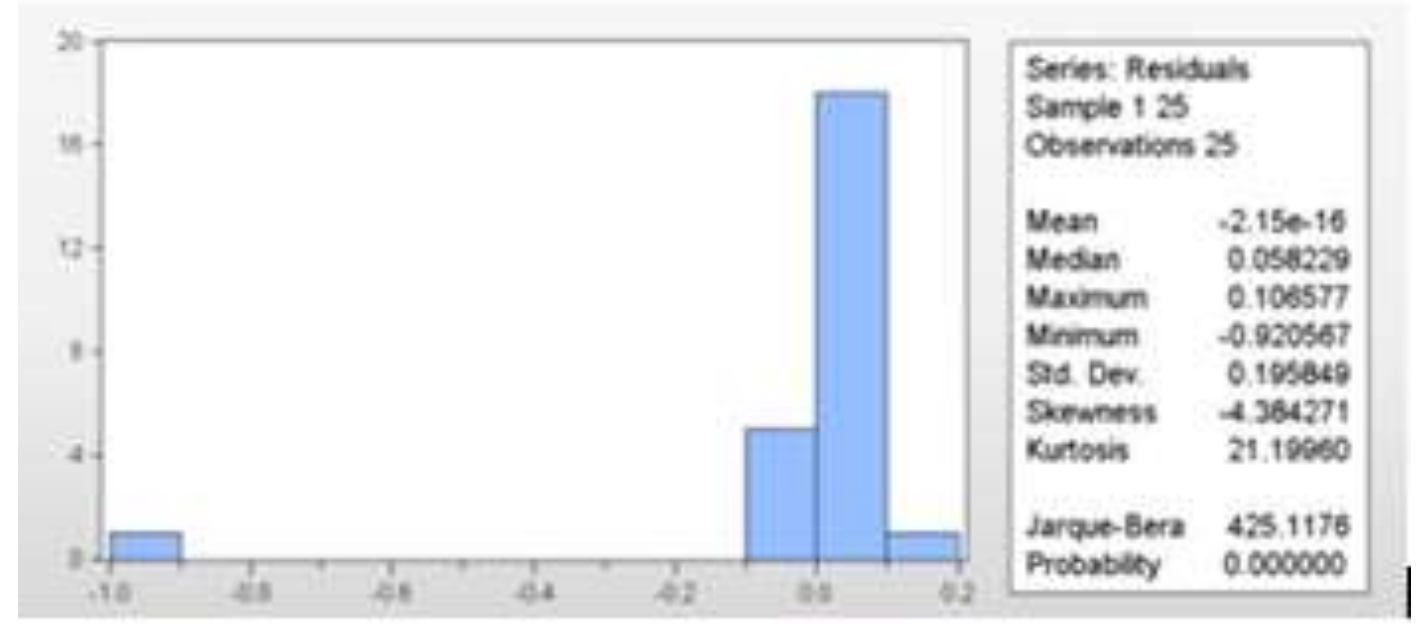

Sumber: Hasil Penelitian (2021)

Gambar 1. Hasil Uji Normalitas

Dari hasil pengujian menggunakan Eviews, diperoleh nilai Jargue-Bera Probability sebesar 0,00 . Dikatakan data berdistribusi normal apabila nilai probabilitas lebih besar dari $5 \%$ ( $P$ value $>0,05)$, sehingga dari hasil ini nilai JB Probability lebih besar dari $0,05(0,00>0,05)$ sehingga dapat dikatakan data tidak berdistribusi normal.

\subsection{Uji Parsial}

Uji berikutnya dari estimasi regresi adalah Uji Parsial (Uji t). Uji t merupakan uji statistic yang bertujuan untuk melihat pengaruh variable bebas secara individual (parsial) terhadap variable terikat. Syarat untuk mengetahui variabel bebas mempunyai pengaruh terhadap variabel terikat dapat diketahui, jika Prob. $>\alpha(5 \%)$, maka HO diterima dan Jika Prob. $<\alpha(5 \%)$, maka tolak $\mathrm{HO}$.

Uji parsial menjadi bagian dari uji statistik yang bertujuan mengetahui secara partial apakah variable independen memiliki pengaruh terhadap variable pengikat.

Tabel 4. Hasil Uji Parsial

\begin{tabular}{cccc}
\hline Variabel & Coefficient & t-Statistic & Prob. \\
\hline D2 & $-0,917238$ & $-7,87001$ & 0 \\
\hline D3 & -0.912982 & $-3,981305$ & 0,0007 \\
\hline C & $-0,241296$ & -0.154733 & 0,8786 \\
\hline GCG & 0,013525 & 0,762992 & 0,4544 \\
\hline SOLVA & $-0,093293$ & $-0,070572$ & 0,9444
\end{tabular}

Sumber: Hasil Pengolahan Data (2021)

Dari hasil analisis, dapat diketahui nilai Prob. < a (5\%), variable GCG mempunyai pengaruh terhadap peringkat obligasi dengan nilai Probabilitas 0,4544 atau kurang dari $\alpha 5 \%$, sedangkan rasio solvabilitas tidak mempunyai pengaruh terhadap pertumbuhan ekonomi dengan nilai probabilitas 0,944 atau lebih dari a $5 \%$. Sehingga dapat disimpulkan persamaan regresi sebagai berikut:

$$
P O=-0.241296+0.013525 G C G-0.093293 \text { Solva }+e
$$


Dari hasil persamaan regresi tersebut dapat dijelaskan sebagai berikut: a) Intersep sebesar -0.241296, menunjukkan ketika GCG dan Rasio Solvabilitas tidak mengalami perubahan, maka peringkat obligasi akan turun sebesar -0,241296; b) GCG sebesar 0,013525, menunjukkan ketika GCG mengalami perubahan sebesar 1, maka peringkat obligasi akan meningkat sebesar 0,013525 ; c) Rasio Solvabilitas sebesar -0,093293, menunjukkan ketika rasio solvabilitas mengalami perubahan sebesar 1, maka peringkat obligasi justru akan menurun sebesar $-0,093293$.

Sementara itu hasil pengujian uji parsial pada table 4, dapat dirinci hasil uji t pengaruh Good Corporate Governance terhadap peringkat obligasi dan Hasil uji t pengaruh rasio solvabilitas terhadap peringkat obligasi

Hasil uji t pengaruh Good Corporate Governance terhadap peringkat obligasi, menurut Indonesian Institute of Corporate Governance (IICG), Corporate Governance merupakan rangkaian metode guna membimbing serta mengelola perusahaan agar dapat beroperasi sesuai dengan keinginan stakeholders.

Secara parsial uji t diperoleh nilai t statistic untuk variabel Good Corporate Governance sebesar 0.762992 sedangkan nilai t tabel sebesar 0.686 dengan nilai signifikan $0.4544>0.05$. Maka disimpulkan bahwa $\mathrm{H} 0$ ditolak dan $\mathrm{H} 1$ diterima atau secara parsial variabel Good Corporate Governance berpengaruh positif signifikan terhadap peringkat obligasi pada perusahaan industri perbankan.

Hasil penelitian ini didukung oleh penelitian yang dilakukan oleh (Sari \& Yasa, 2016). Hasil penelitian secara parsial variabel Good Corporate Governance yang diproksikan dengan Corporate Governance Perception Index (CGPI) berpengaruh positif dan signifikan terhadap peringkat obligasi.

Hasil uji $\mathrm{t}$ pengaruh rasio solvabilitas terhadap peringkat obligasi menunjukkan kemampuan perusahaan dalam memenuhi kewajibannya ketika perusahaan tersebut dilikuidasi. Dengan demikian, solvabilitas adalah kesanggupan perusahaan untuk melunasi semua hutang-hutangnya, baik jangka pendek ataupun jangka panjang.

Secara parsial uji t diperoleh nilai t statistic untuk variabel Solvabilitas sebesar 0.070572 sedangkan nilai t tabel sebesar 0.686 dengan nilai signifikan $0.9444>0.05$. Maka disimpulkan bahwa $\mathrm{H} 0$ diterima dan $\mathrm{H} 1$ ditolak atau secara parsial variabel Solvabilitas tidak berpengaruh signifikan terhadap peringkat obligasi pada perusahaan industri perbankan.

Hasil penelitian ini berbanding terbalik dengan penelitian yang dilakukan oleh (Sari \& Yasa, 2016). Penelitian yang dilakukan difokuskan pada perusahaan yang terdaftar di Bursa Efek Indonesia tahun 2002-2013 dari berbagai sektor dengan total sampel 70 perusahaan penerbit obligasi. Dan hasil penelitian yang diperoleh yaitu perusahaan yang menggunakan dana pada aktivitas operasi lebih banyak dibandingkan dengan dana yang diterima dari aktivitas operasi 


\section{Pengaruh Penerapan Good Corporate Governance dan Solvabilitas Terhadap Peringkat Obligasi Pada Industri Perbankan}

\section{Kesimpulan}

Good Corporate Governance berpengaruh positif signifikan terhadap peringkat obligasi pada perusahaan industri perbankan. Hal ini menunjukkan jika perusahaan memiliki skor CGPI yang tinggi, berarti perusahaan tersebut telah menerapkan tata kelola perusahaan yang baik dan perusahaan tersebut adalah perusahaan yang layak untuk menjadi tempat berinvestasi bagi para investor, karena perusahaan memiliki peringkat obligasi yang terpercaya. Solvabilitas tidak berpengaruh signifikan terhadap peringkat obligasi pada perusahaan industri perbankan. Hal ini disebabkan oleh rendahnya nilai rata-rata CFOTL selama periode penelitian. Sementara saran yang dapat diberikan, antara lain: a) Perusahaan harus sungguh-sungguh menerapkan prinsip-prinsip tata kelola perusahaan yang baik. Dan bisa menjaga prestasi yang sudah diraih; b) Investor diharapkan bisa lebih uptodate mempelajari informasi obligasi. Laporan keuangan dan peringkat obligasi dapat membantu investor menentukan apakah suatu perusahaan memiliki obligasi berkualitas tinggi; c) Penelitian hanya menguji dua variabel bebas, yaitu Good Corporate Governance dan Solvabilitas dapat diakui dengan beberapa ukuran. Hal ini merupakan salah satu keterbatasan penelitian yang tidak menguji variabel lain. Sehingga untuk penelitian selanjutnya, disarankan untuk mengganti variabel solvabilitas dengan Debt to Assets Ratio (DAR) atau Long Term Debt to Equity Ratio (LTDER), dan menambahkan variabel independen seperti likuiditas atau profitabilitas. Selain itu, peneliti selanjutnya dapat melakukan penelitian di Lembaga pemeringkat obligasi lainnya, seperti PT Fitch Ratings Indonesia.

\section{Daftar Pustaka}

Amalia, N. (2013). Pemeringkatan Obligasi Pt Pefindo: Berdasarkan Informasi Keuangan. Accounting Analysis Journal, 2(2). https://doi.org/10.15294/aaj.v2i2.2879

Bhagat, S., \& Bolton, B. (2019). Corporate governance and firm performance: The sequel. Journal of Corporate Finance, 58, 142-168. https://doi.org/10.1016/j.jcorpfin.2019.04.006

Bornok Situmorang. (2017). Pengaruh Peringkat Obligasi, Debt to Equity Ratio, dan Ukuran Perusahaan Terhadap Yield To Maturity Obligasi Dengan Tingkat Suku Bunga SBI Sebagai Variabel Moderating (2010-2013). Jurnal Terapan Manajemen Dan Bisnis, January 2018.

Damayanti, E. W., \& Fitriyah, F. (2013). Pengaruh Corporate Governance Dan Rasio Akuntansi Terhadap Peringkat Obligasi. Iqtishoduna. https://doi.org/10.18860/iq.v0i0.2281

Hidayat, W. W. (2018). Pengaruh Leverage Dan Likuiditas Terhadap Peringkat Obligasi. Jurnal Riset Manajemen Dan Bisnis (JRMB) Fakultas Ekonomi UNIAT, 3(3), 387-394. https://doi.org/10.36226/jrmb.v3i3.155

Janiman, J., Burhanudin, M., \& Yulianto, A. (2017). Peringkat Obligasi Ditinjau dari Produktivitas dan Penerapan Corporate Governance Perception Index (CGPI). Jurnal Kajian Akuntansi, 1(2), 172-183. https://doi.org/10.33603/jka.v1i2.765

Ningsih, S., \& Sari, S. P. (2019). Analysis Of The Effect Of Liquidity Ratios, Solvability Ratios And Profitability Ratios On Firm Value In Go Public Companies In The Automotive And 
Component Sectors. International Journal of Economics, Business and Accounting Research, 3(4), 351-359.

Pramono, C., \& Irawan. (2017). Analisis Faktor-Faktor Harga Obligasi Perusahaan Keuangan Di Bursa Efek Indonesia. Jurnal Akuntansi Bisnis Dan Publik, 8(1), 62-78.

Sari, I. K., \& Yasa, G. W. (2016). Pengaruh Penerapan Good Corporate Governance, Profitabilitas dan Likuiditas terhadap Peringkat Obligasi. Journal of Chemical Information and Modeling, 53(9), 1689-1699.

Sitorus, T. (2015). Pasar Obligasi Indonesia : Teori dan Praktik. PT RajaGrafindo Persada.

Sunarjanto, N., \& Tulasi, D. (2013). Kemampuan Rasio Keuangan Dan Corporate Governance Memprediksi Peringkat Obligasi Pada Perusahaan Consumer Goods. Jurnal Keuangan Dan Perbankan, 17(2), 230-242.

Titisari, K. H., Winanti, E., \& Nurlaela, S. (2017). Pengaruh Rasiolikuiditas, Rasio Produktivitas, Rasio Profitabilitas, Dan Rasio Solvabilitas Terhadap Peringkat Sukuk. Jurnal Akuntansi Dan Pajak, 18(01), 130-139. https://doi.org/10.29040/jap.v18i01.90 